\title{
Students' View of the Management Information and Document Study Program of the Class of 2015 University of Indonesia Vocational Education Program to Librarian Profession in a Digital Age
}

\author{
Dyah Safitri ${ }^{1}$ \\ ${ }^{1}$ Management Information and Document, Vocational Education Program, Universitas Indonesia \\ Depok, West Java, Indonesia \\ dyah.mid@gmail.com/dyah.s@ui.ac.id
}

\begin{abstract}
Vocational education in librarianship faces digital era challenges. There are some barriers that librarians will need to overcome to compete amidst these challenges. On this note, this research seeks to evaluate students' responses to the Management Information and Document (MID) Program of the Class of 2015 University of Indonesia vocational student's response to the future of librarianship in the digital era. The research used the online survey method of the students of the MID Class of 2015. The results showed that students should be prepared for more education after the vocational training to competitively meet the needs of the digital library user.
\end{abstract}

Keyword: librarianship, digital era, digital library

\section{Introduction}

\subsection{Background}

The world has entered the digital age, characterized by the widespread use of information and communication technologies that strive to improve knowledge at a high speed. People's behavior has also changed, such as how they get and use information, including how they access library resources. The digital era also marks how everything becomes digital, such as the economy, the knowledge economy, and the library. The transformation of the field of information and communication technology (ICT) has made this possible.

We get medical information, news, pictures, and videos easily as electronic mail from the internet. Colleges and universities become vulnerable, especially for librarians, whether to continue to struggle to shift Google's reputation or how to pair them with better library services (Herring, 2014). In short, almost all sectors are affected by the development of information and communications technology, including private space.

The development in the digital era has also been realized by the Study Program of the Management of Information and Document (MID). Work in the field of library and information became one of the outputs of the Study Program of the MID of the Vocational Education Program at the University of Indonesia (UI). The MID study program incorporates the library and archival sciences, as well as information education. The graduates are expected to be able to handle general information, document management tasks, and to complete the practical professional tasks with a high quality of expertise, as well as the ability to make decisions regarding the management, assessment, and use of information and documents (Program Studi Manajemen Informasi dan Dokumen, 2018).

The MID study program prepares graduates who are ready to work, emphasizing on mastering the practical skills of each course that will support the needs of the work. The students will use the laboratories and facilities owned by the study program to adapt to those needs. The curriculum of the study program is constantly updated and focused on the specificity of the capabilities. The Class of 2015 MID was the last class to obtain the library and archival sciences together. After this class, the MID course will focus on archival science only.

\subsection{Statement of Problem}

Based on the background provided above, it will be interesting to observe how students of the Class 2015 MID will look at the profession of the librarian in the digital era. Some of the consequences of the digital era are more open information and information floods. It places librarians and library professionals at crossroads. On the one hand, it is easier for people to access information technology, but on the other hand, there are still some people who need and depend on the library as a source of information. The role of librarians must be dynamic in the face of the digital age. It will be interesting to examine how the MID graduates, as ready-to-use personnel who have special skills in the field of libraries, look at the librarian profession and libraries in the future. 
The questions asked are:

1. How do the students of Class 2015 MID view the librarian's profession in the digital age as it is today?

2. Can the knowledge and skills they acquired while attending college support their work later in the library and information field?

3. Will they continue their education after completing the diploma program?

\subsection{Research Objectives}

This research seeks to know the views of the students of Class 2015 MID study program on the librarian profession in the digital era. The theoretical goal is to provide theory contributions to the work desired by students when they learn the application of education and teaching in the MID study program Vocational Education Program at the UI.

\subsection{Study Limitations}

This research uses only the population of the Class of 2015 MID students; hence, its application is limited to this class and cannot be generalized.

\section{Theoretical Framework}

A long time before the internet was developed and was made more accessible worldwide, a British scientist, James Thompson, shocked the public (Thompson, 1983). The situation of the library will be surrounded by the existence of technology, a combination of computers where information can be stored, processed, and can be combined with telecommunications to facilitate the transmission of information to people all over the world. The library does not need to be visited, it does not need a catalog card, the rack does not need to be searched, and the book does not need to be scanned. This will mark the change of society as did the discovery of railroads and electricity in the 19 th century.

This view echoes the scale of socio-economic transformation, which the Industrial Revolution brought about long before the digital era began (Shepard, 2004). Daily life in the digital era is increasingly varied with the use of ICT. This way, there is an increase in knowledge at a high speed, and it has the nature of addiction by being out of control but enabling more productivity due to the absence or shriveling of distance. The digital age transforms the social economy of society into knowledge because of the increasingly dynamic and complex social and geographical community of the economy. The internet becomes the key to how society becomes more knowledgeable because access to information becomes easier.

Now, such predictions (Thompson, 1983; Shepard, 2004) have come true. The internet has become an integral part of societies around the world. The rapid informational connections across the world ensure that there is no more information gap between one country and another and between one region and another. This makes it possible for everyone to access information freely. As a result, the problems faced by libraries and librarians, as said by Thompson, have become a reality. Lost catalog cards can now be replaced by online catalogs, physical books can be replaced with electronic books, and library services can be done online. Thus, libraries and librarians need a new meaning in the digital era.

It is not easy for libraries to adapt to these changes. Librarians should take advantage and avoid the weaknesses of digital sources. Some Asian countries have adapted to the existence of the digital era. India, for example, has a goal with the National Virtual Library of India to provide access to information in an openaccess environment. This concept began in the mid-1990s with support from the Central Government (Suresha \& Kirana, 2017) China stresses that the growing digital age can be used by the library science community and related industries, especially the ICT industry (Darwish, 2014). In Taiwan, most libraries are already at the stage of digitizing. Rapid technological developments will make the National Library of Public Information different from traditional libraries (Huang, 2015). Vietnam has a slightly different policy of rapid technological developments that must be balanced with the librarian's self-development. A number of institutions are cooperating from Singapore, Australia, and the United States (Tran, 2015).

So, what about Indonesia? Developing countries in the ASEAN countries - except Singapore - are in the process of developing digital libraries (Zen, 2014). Not only in the National Library, but also in other areas, such as college libraries, school libraries, and public libraries. The stages begin with the use of ICTs for library automation and the introduction of digital services.

Such developments should always be anticipated by the librarian as a professional. Librarians must develop themselves with new knowledge and skills in order to anticipate the needs of today's users. The common skills that need to be constantly developed include communication and interpersonal skills, critical thinking, problem- 
solving, and teamwork that will enable them to continue to improve personal competence (Raju, 2014). The concept of communication today is a participation-based one that expresses horizontal, two-way, and balanced communications. The goal is doing something together, sharing references, ideas, and knowledge. The librarian can become an online librarian as a supporter of new information, evaluate books read, and participate in book acquisition, to give the idea of library development and obtain information not only from libraries but also from other librarians (Xie \& Stevenson, 2014). The use of social media can also be an alternative in the face of the digital age. The provision of information, marketing and promotion, sharing of information, and connecting one person to another is a social media function in line with libraries in the digital age (Einastu, 2015).

Librarians in the digital age should re-think their role as more collaboration with the community will enable them become more professional, though the era has changed to digital. The focus remains serving the audience (Palfrey, 2016) . Especially for college libraries, the digital age transforms readers in terms of how they write scientific papers and search for literature sources at a time when the available literature is abundant in a digital format (Gupta, 2017). In order to anticipate this, the education of librarians must consider these factors. In fact, development in the digital age can be used for knowledge sharing through online discussion and direct participation in the classroom. Collaborative learning allows the teaching process to be more interactive, engaging, and more interesting. This model also allows critical thinking skills to be spurred and communication skills to be improved (Majid, Yang, Lei, \& Haoran, 2014).

To achieve this, librarian education must be tailored to anticipate current and ongoing trends. The education of librarians should build student skills and professional practices with ICT support. With that ability, librarians and library user adaptations become equivalent to speaking the same language that is used in the digital era (Einastu, 2015).

So, will the library die? This opinion is dismissed with the argument that librarians can adapt to the digital age. They can adapt to technological developments, based on excellent service, daring to take risks by changing the environment, and making technology a differentiator in libraries (Herring, 2014). The new meaning of libraries can be that they are problem solvers, bridge builders, chasers, as well as teachers who guide students to obtain information from the internet. With non-stop data streams across state boundaries, which are accessible to the public, the work of a librarian is no longer just a book deal but more than that to build information literacy. Hence, the work of a librarian becomes more interesting, more complicated, and more needed by society (Hagen-McIntosh, 2016).

\section{Methodology}

\subsection{Research Design}

This research uses quantitative methods to evaluate the Class of 2015 MID student's view of librarianship in the digital era. Quantitative research is often referred to as a traditional, positivistic, and scientific method. Quantitative methods can be interpreted as a philosophy-based method of positivism using populations or samples. The data in this study used the survey method to analyze the entire population using a series of questions as the basis of data collection.

\subsection{Subjects and Research Location}

The research subjects for this project are students of the MID Class of 2015 who are currently still obtaining teaching materials in the field of library and information. The location of the research is in the Vocational Education Program Campus of the UI, Depok.

\subsection{Population}

The population in this research refers to all the students of the MID Class of 2015 who were 67 in total.

\subsection{Type and Data Sources}

This research used primary data. The data about their views on the librarian's profession in the digital era were obtained from questionnaires distributed to all the MID students of the Class of 2015.

\subsection{Data Collection Techniques}

The method of data collection is through online surveys and questionnaires, using Google Docs, which were filled out by all members of the MID Class of 2015. The questionnaires could be answered by using computers or cell phones 


\section{Findings and Analysis}

\subsection{Respondents}

Respondents in this study were dominated $(89.6 \%)$ by high school graduates of 2015 . The rest were high school graduates of 2013 and 2014 (Fig.1).

Tahun kelulusan SMA

67 responses

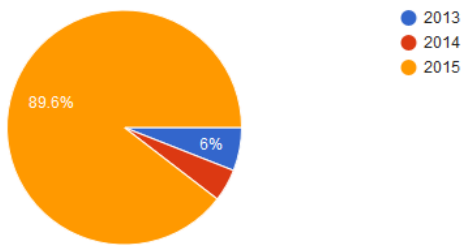

Fig. 1 Table of high school graduates from MID students class 2015 of Vocational UI

The respondents were dominated by female students (56.7\%), while $43.3 \%$ were males (Fig.2)

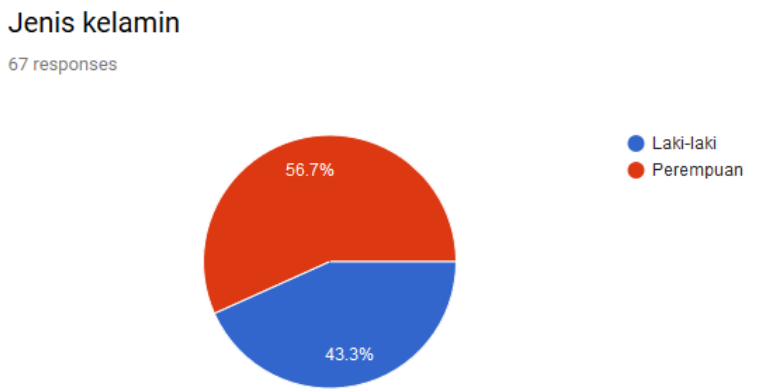

Fig. 2 Student's gender MID Vocational UI class of 2015

The student's MID Vocational Education Program UI Class of 2015 MID was dominated by the Seleksi Masuk (SIMAK) UI (73.1\%), while others are through the invitation path (Fig.3).

Masuk UI melalui jalur :

67 responses

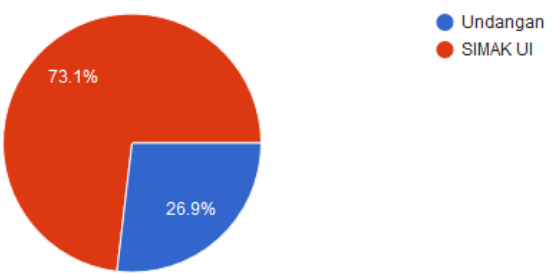

Fig. 3 Entrance to University of Indonesia through test or invitation path

Respondents were dominated by 2015 high school graduates, made up of more women than men. They are more likely to enter the Vocational UI through the entrance examination or the SIMAK UI pathway than by invitation. This evenly distributes the ability of the students .

\subsection{Response to the Profession of Librarians in the Digital Era}

The digital era marked by the Class of 2015 MID students is such that the majority of the students are able to connect from anywhere and anytime. Overall, $1.3 \%$ did not have internet accessibility, while $29.9 \%$ have 
internet accessibility. The digital era was also associated with more open information (26.9\%) and information flood (11.9\%) (Fig.4).

\section{Di era digital, menurut Anda apa ciri khusus dari era tersebut (pilih salah satu) \\ 67 responses}

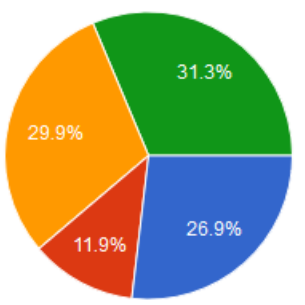

Informasi le bih terbuka

- Banjir informasi

Kemudahan akses internet

Dapat terhubung kapan saja dan

dimana saja

Fig. 4 Characteristics of the digital era

In the response to the questionnaires about what the library should do when dealing with the digital era, the majority answered that knowledge about the digitalization of the library $(67.2 \%)$ is needed. Others responded that knowledge of services in the digital age (65.7\%), digital knowledge such as social media (59.7\%), and knowledge of digital library policy (40.3\%) are important (Fig 5).

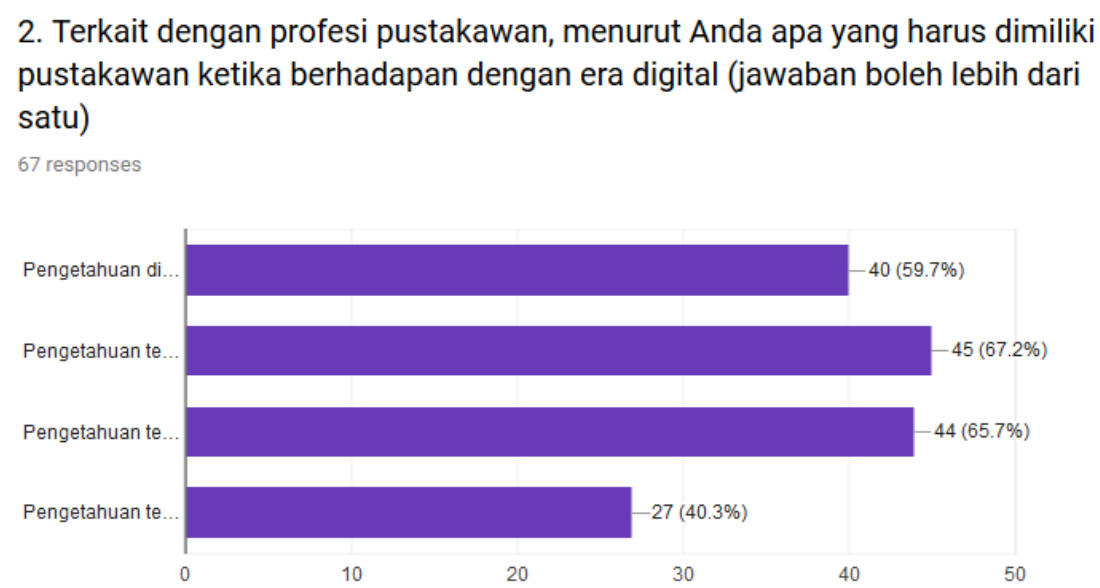

Fig. 5 Librarian's Knowledge in the Digital Age

The library in the digital age has a tough challenge. Respondents chose that the younger generation was less interested in libraries (43.3\%), while others (28.4\%) ascribed this to lower literacy culture. Interestingly, only $9 \%$ answered that the community no longer cares about the library (Fig 6).

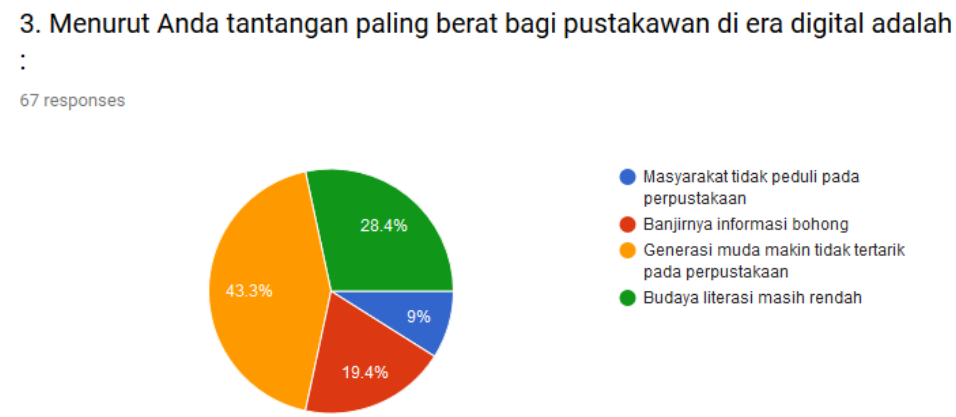

Fig. 6 Challenges for librarians in the digital era 
About what should be mastered by a librarian in the digital age, the predominant response was that everything needs to be mastered (89.6\%). Others said computer applications (28.4\%), internet (23.9\%), and social media (22.4\%) (Fig.7).

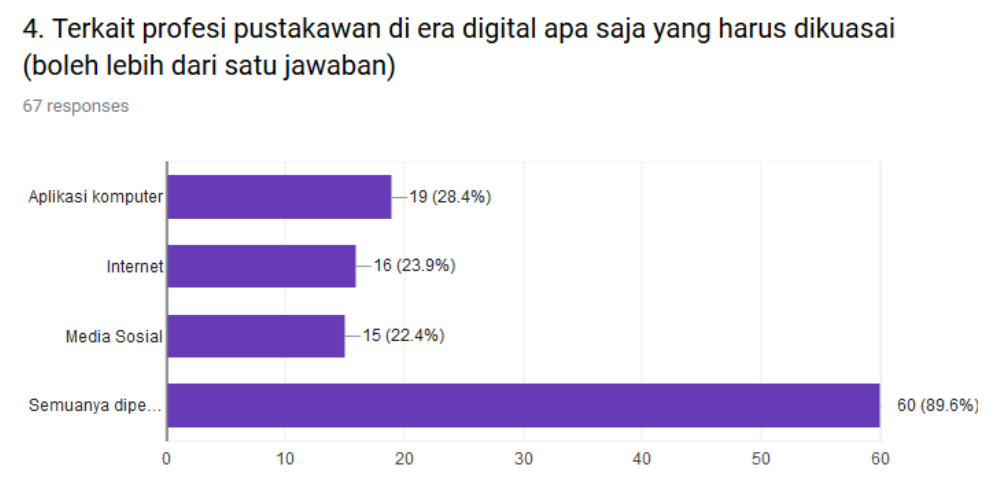

Fig. 7 What librarians should master in the digital age

Related to what services librarians need in the digital age, the majority answered that it is digital information literacy $(89.6 \%)$, two-way communication $(68.7 \%)$, digital book borrowing $(61.2 \%)$, and digital library promotion $(61.2 \%)$ (Fig 8$)$.

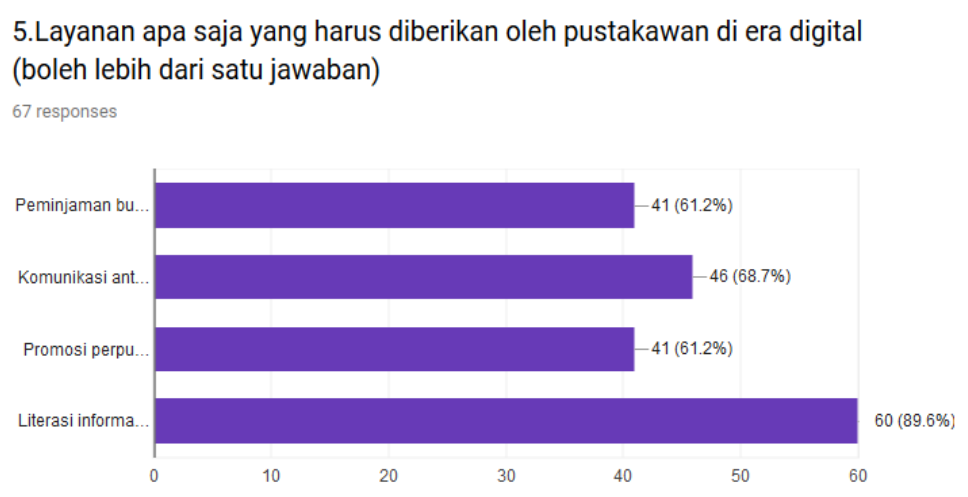

Fig. 8 Services to be delivered in the digital age

Communication between librarians and readers becomes very important in the digital age. Respondents answered that the communication should be done through digital base $(47.8 \%)$, communication should be without division $(26.9 \%)$, and direct communication should be more intense $(13.4 \%)$. Nevertheless, there are $11.9 \%$ who answered that communication should be tiered (Fig. 9).
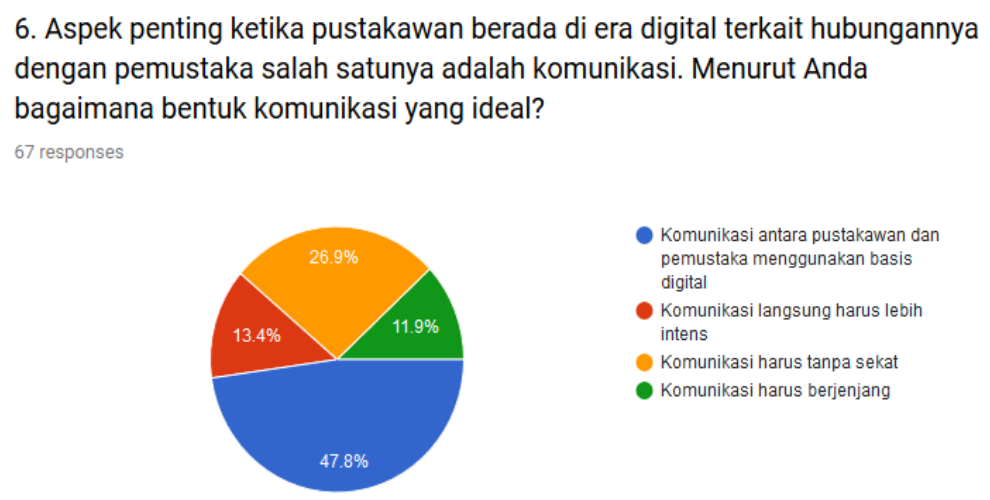

Komunikasi antara pustakawan dan pemustaka menggunakan basis digital

Komunikasi langsung harus lebih

- Komunikasi harus tanpa sekat

- Komunikasi harus berjenjang

Fig. 9 Communication Between Librarian-User in Digital Era 
The ideal librarian figure in the digital era in the respondents' view is that they are capable of synchronizing physical activity and digital capabilities (41.8\%). Others believe that they are able to update with changes in culture and technology in the community $(25.4 \%)$, that they can adapt to the digital condition of the community $(23.9 \%)$, and can always act from the perspective of users (9\%) (Fig. 10).
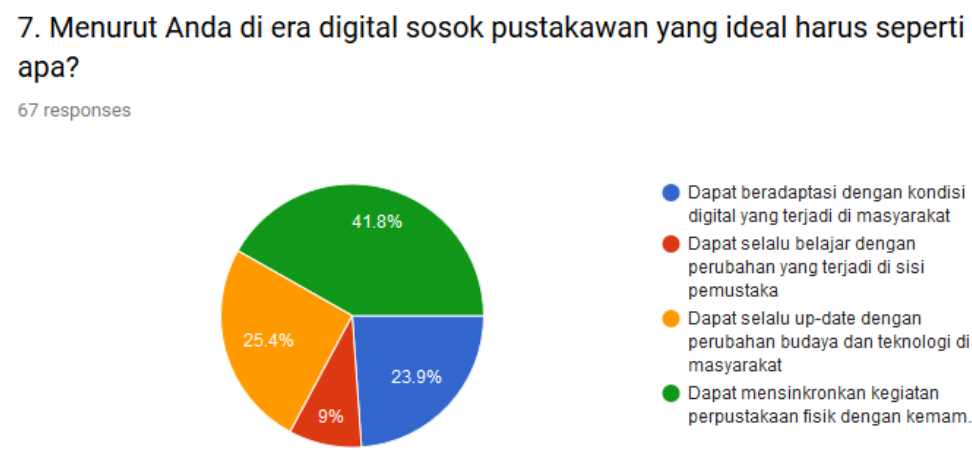

- Dapat beradaptasi dengan kondis

Dapat selalu belajar dengan
perubahan yang terjadi di sisi perubahan yang terjadi di sis

Dapat selalu up-date dengan

perubahan budaya dan teknologi di

masyarakat

Dapat mensinkronkan kegiatan

perpustakaan fisik dengan kemam.

Fig. 10 Ideal Librarians in the Digital Age

Responses of students to the provision they get from lectures in Prodi MID as follows:

- The majority $(89.6 \%)$ reported that they received adequate library knowledge, while the remaining students (10.4\%) said they did not get the supplies (Fig. 11).

\section{Selama belajar di program studi Manajemen Informasi dan Dokumen apakah Anda memperoleh bekal ilmu perpustakaan yang memadai \\ 67 responses}

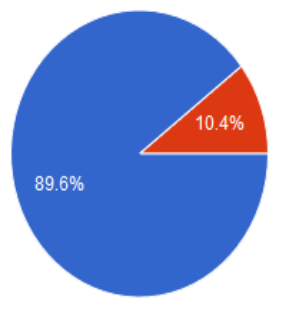

Ya

Tidak

Fig. 11 Provision of library science at Lectures

- Majority of the respondents answered that they have the hard skills needed when they later work in the library $(70.1 \%)$, while the remaining students $(29.9 \%)$ felt they have not obtained adequate hard skills (fig.12).

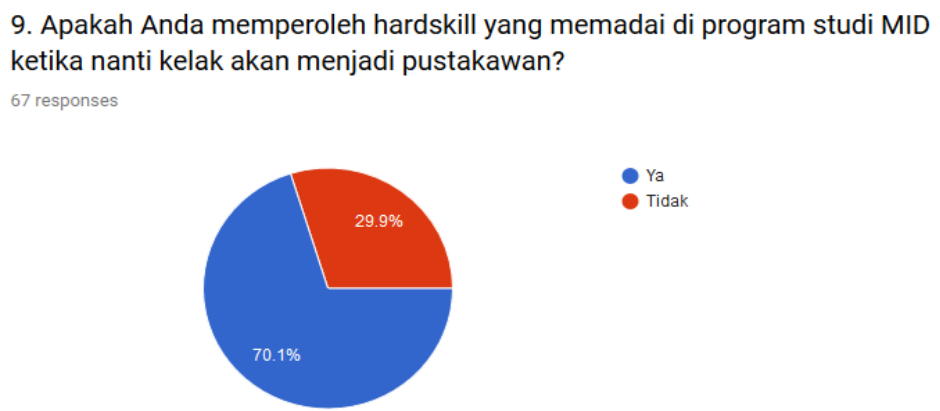

Fig. 12 Hardskill of library science 
- $\quad$ For the soft skills stock, the majority (91\%) answered that they have obtained enough during college, while the remaining students $(9 \%)$ said they have not adequately obtained the soft skills.

The digital age, according to respondents, is marked by being able to connect with the world anywhere and anytime. This is also a big challenge for libraries because librarians have to be digitally literate. A very difficult challenge for them is that young people are not currently interested in libraries. Thus, librarians must master digital information literacy.

The face of the library must change. The classic book lending service should be combined with digital capabilities as well as interactive communication skills with users. Hence, the capacity of the librarian, besides mastering librarianship, should involve a two-way communication with users. The students in this study reported that they have gained knowledge about everything related to the library via the Vokasi UI, with sufficient hard skills.

\subsection{Response to Advanced Studies}

This study also reported on how the students hone their skills and improve their knowledge. When asked about whether they intend to continue their studies after graduating, $85.1 \%$ said they will continue, and the remaining $14.9 \%$ said they will not (Fig. 13).

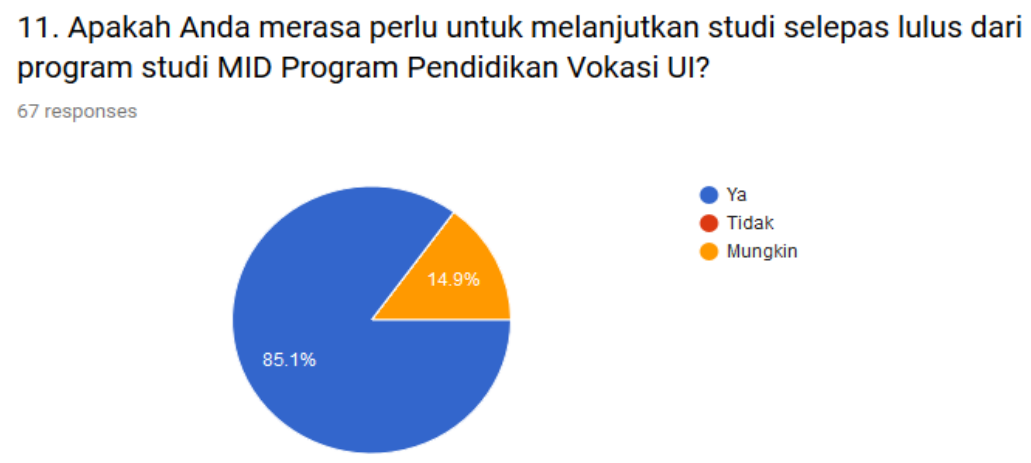

Fig. 13 Further study after graduation

The selected advanced study program is quite interesting because $56.7 \%$ will continue to the S1 degree outside the field of library science, $32.8 \%$ will continue within the S1 field of library science, while the rest will pursue D4 library (Fig. 14).

12. Jika ya atau mungkin, program studi apakah yang akan Anda pilih setelah lulus dari Program Vokasi UI

67 responses

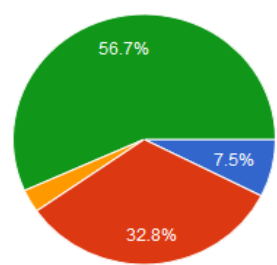

D4 IImu Perpustakaan

D1 IImu Perpustakaan

- $\$ 1$ bidang ilmu lainnya

Fig. 14 Study Program chosen after graduating from MID UI Vocational Program

When further explored in terms of why they choose S1 or D4 library science, $64.7 \%$ of the respondents answered that they need more knowledge in supporting the profession, $21.6 \%$ answered that they have no other choice, and $13.7 \%$ said the program should be linear (Fig. 15). 


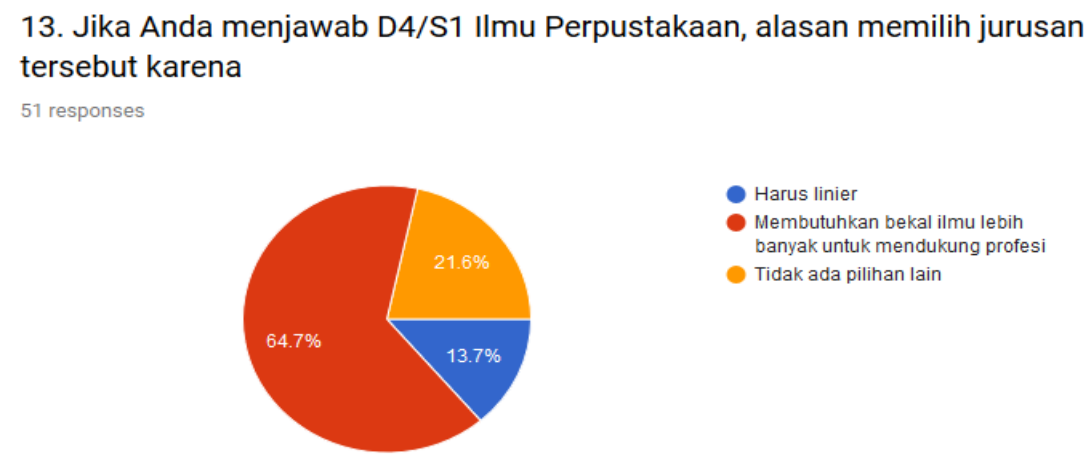

Fig. 15 Reasons for choosing advanced study of library science

For those who will continue to study outside library science, $34.8 \%$ expressed the opinion that there is no advanced study program from D3 library science, $34.8 \%$ believe that the digital era makes the librarian profession to have less future prospects, and $30.4 \%$ feel they will be unable to keep up with traditional library change to digital library (Fig. 16).

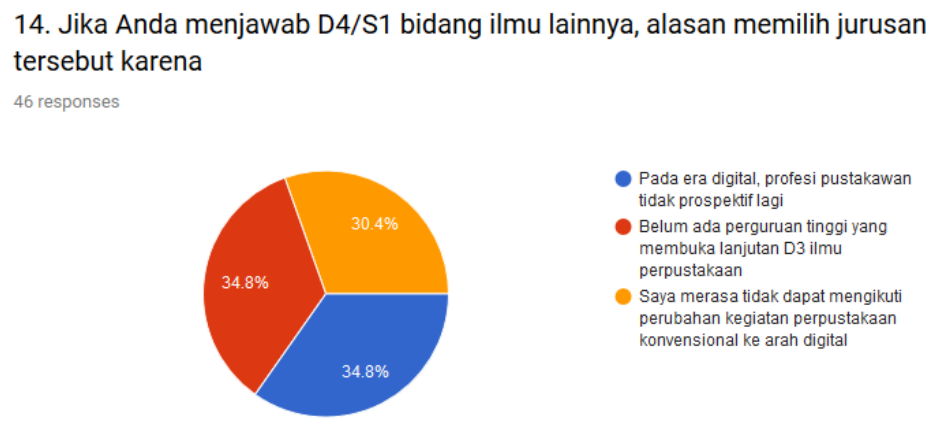

Fig. 16 Reasons for choosing advanced study outside of library science

Education is very important for respondents. They want to continue their studies to a higher level. If there is a D4 program of library science, it will be linear with the current study. Another big challenge, according to respondents, is that libraries are believed to have less future prospects, so they are thinking of continuing their studies outside the library study path.

\subsection{Suggestions}

The digital era is inevitable, and its influences include the library world. This era can be anticipated early on by adequately preparing prospective librarians. Hard skills in the fields of computers and the internet are increasingly needed as one of the elements of the course that is very important to adapt students to the development of the era. On the soft skills side, creative communication skills must be developed in students to make them more open, able to engage in two-way communications and give each other the knowledge and information characteristic of the digital era.

\section{Conclusion}

The answers provided by respondents give an overview of how the students of the MID Vocational Education Studies Program look at the librarian's profession in the digital age. From these answers, it can be concluded that the challenges in the digital era should be anticipated by still prioritizing the improvement of the self-ability of the MID graduates when they later accept work as librarians. It is believed that the acquisition of soft skills and hard skills during college will help them when they start working as librarians.

However, the digital age also underscores how they need to adapt. This is reflected in how they will continue their studies because the majority chose not to continue in the same area due to the lack of a major in 
library science from a diploma to a graduate or undergraduate degree. However, this is an opportunity for colleges that can provide majors in accordance with the needs of the workforce so that the digital era will be interpreted as a process of capacity building and improvement of self-capabilities for librarians.

\section{Acknowledgments}

This research is supported by Vocational Education Program UI. I thank Prof. Sigit Pranowo Hadiwardoyo, DEA and Padang Wicaksono, $\mathrm{PhD}$ for his knowledge and deepening of the research side. I would also like to thank all the students MID Class of 2015 who have participated in filling out the survey questionnaire using computer or mobile phones.

\section{References}

Darwish, P. (2014). Chinese librarianship in the digital era. The Australian Library Journal, 63(3), 255-256. doi:10.1080/00049670.2014.939359

Einastu, O. Transforming library communication: from Gutenberg to Zuckerberg. New Library World, 116(5/6), 252. doi:10.1108/nlw-05-2014-0055

Gupta, V. (2017). Impact of digitalisation of academic institutional libraries on research in internet age: A study. International Journal of Knowledge Management and Practices, 5(1), 1.

Hagen-McIntosh, J. (Ed.). (2016) Information and data literacy: The role of library. Oakville, Canada: Apple Academic Press Inc.

Herring, M.Y. (2014). Are Libraries Obsolete? An Argument for Relevance in the Digital Age. Jefforson, NC: McFarland \& Company Inc. Publishers.

Huang, T. C. (2015). What Library 2.0 has taught libraries in Taiwan about e-learning. The Electronic Library, 33(6), 2015, 1121-1132. doi:10.1108/EL-04-2014-0070

Majid, S., Yang, P., Lei, H., \& Haoran, G. (2014). Knowledge sharing by students: preference for online discussion board vs face-to-face class participation. The Emergence of Digital Libraries - Research and Practices Proceeding International Conference on Asia-Pacific Digital Libraries, ICADL,158. doi:10.1007/978-3-319-12823-8_16

Palfrey, J. (2016). Design choices for libraries in the digital-plus era. Journal of the American Academy of Arts \& Sciences, 145(1), 79-86. doi:10.1162/daed_a_00367

Program Studi Manajemen Informasi dan Dokumen. Retrieved April 15, 2018, from http://vokasi.ui.ac.id

Raju, J. (2014). Knowledge and skills for the digital era academic library. The Journal of Academic Librarianship, 40(2), 163-170. doi:10.1016/ j.acalib.2014.02.007

Shepard, J. (2004). Why the digital era? In G. Doukidis, N. Mylonopoulos, N. Pouloudi (Eds.), Social and Economic Transformation in The Digital Era (pp. 1-18). Hersey, USA: Idea Group Publishing.

Suresha, G.P., \& Kirana Kumar, D. (2017). Digital libraries in India: A discretional perspective on present scenario. International Research: Journal of Library \& Information Science, 7(3), 525.

Thompson, J. (1983). The end of libraries. The Electronic Library, 1(4), 245-255. doi: 10.1108/eb044603

Tran, H. (2015). Challenges in the digital information era Situation at the General Sciences Library of HoChiMinh City. Library Management, 36(4/5), 315-328. doi: 10.1108/LM-08-2014-0096

Xie, I., \& Stevenson, J. (2014).Social media application in digital libraries. Online Information Review, 38(4), 502-523. doi:10.1108/oir-11-2013-0261

Zen, Z. (2014). Professional development of Indonesian librarians towards Digital Library Environment. Al-Ta'lim Journal; Padang, 21(2), 139. doi:10.15548/jt.v21i2.91 